\title{
Solitary Pulmonary Nodule: Morphological Effects on Metabolic Activity Assessment
}

\author{
Soliter Pulmoner Nodül: Metabolik Aktivite Değerlendirmesinde Morfolojik Etkiler

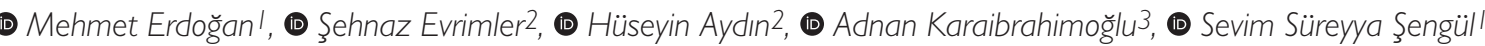 \\ ISüleyman Demirel University Faculty of Medicine, Department of Nuclear Medicine, Isparta, Turkey \\ 2Süleyman Demirel University Faculty of Medicine, Department of Radiology, Isparta, Turkey \\ 3Süleyman Demirel University Faculty of Medicine, Department of Biostatistics and Medical Informatics, Isparta, Turkey
}

\begin{abstract}
Objectives: We aimed to evaluate the effects of morphological characteristics of the solitary pulmonary nodules (SPN) on metabolic activity assessment. To the best of our knowledge, this is the first study to compare the volumetric metabolic activity parameters according to the morphologic parameters of the nodules.

Methods: In this retrospective study, ${ }^{18} \mathrm{~F}$-FDG positron emission tomography and computed tomography scans performed between 2011 and 2018 were evaluated by a nuclear and diagnostic radiologist. One hundred thirteen patients with SPNs with biopsy-proven diagnosis were included. SPNs were classified as solid, partially solid (PS), and ground glass opacity (GGO).

Results: SPN diameter, SUV max' metabolic tumor volume (MTV), total lesion glycolysis (TLG), and density were significantly higher in the malignant group. SUV max' MTV, TLG increased in direct proportion to the diameter. There was no a significant difference between GGO, PS, and solid nodules in terms of SUV $V_{\text {max }}$ values. MTV and TLG values increased in parallel with the density of the nodules, but this increase was only significant in the malignant group. There was a significant difference between SPNs $<2 \mathrm{~cm}$ and SPNs $\geq 2 \mathrm{~cm}$ in terms of MTV, while there was no difference in terms of SUV max . The cut-off value determined by the ROC curve was found to be 4.39 for SUV max' $^{\prime} 7.33 \mathrm{~mL}$ for MTV and $31.88 \mathrm{~g}$ for TLG. The cut-off values for SUV $V_{\max }$ of solid and subsolid nodules were close to each other, but cut-off values for MTV and TLG were higher in solid nodules. Conclusion: SUV max' $_{1}$ MTV, and TLG are affected by diameter and attenuation. We suggest using different MTV and TLG cut-off values for solid and subsolid nodules, but we suggest using same SUV ${ }_{\max }$ values. MTV can be a more reliable parameter than $\mathrm{SUV}_{\max }$ in prediction of malignancy in smaller nodules.
\end{abstract}

Keywords: Positron emission tomography, solitary pulmonary nodule, metabolic tumor volume, total lesion glycolysis

\section{Öz}

Amaç: Soliter pulmoner nodüllerin (SPN) morfolojik özelliklerinin metabolik aktivite değerlendirmesi üzerindeki etkilerini değerlendirmeyi amaçladık. Bildiğimiz kadarılla, volümetrik metabolik aktivite parametrelerini nodüllerin morfolojik parametrelerine göre karşılaştıran ilk çalışma budur.

Yöntem: 2011 ve 2018 yılları arasında yapılan ${ }^{18}$ F-FDG pozitron emisyon tomografisi ve bilgisayarlı tomografi taramaları, bir nükleer tıp uzmanı ve radyoloji uzmanı tarafından retrospektif olarak değerlendirildi. Biyopsi ile kanıtlanmış tanısı olan 113 SPN hastası dahil edildi. SPN'ler solid, kısmi solid (PS) ve buzlu cam opasitesi (GGO) olarak sınıflandırıldı.

Bulgular: SPN çapı, SUV maks' metabolik tümör hacmi (MTV), toplam lezyon glikoliz (TLG) ve dansite malign grupta anlamlı olarak yüksek bulundu.

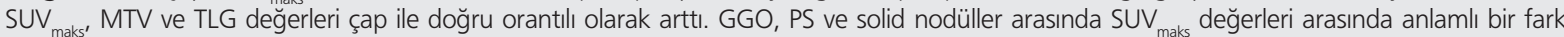
yoktu. MTV, TLG değerleri nodüllerin yoğunluğu ile paralel olarak arttl; ancak sadece malign grupta anlamlı fark bulundu. $2 \mathrm{~cm}$ 'den küçük grupta

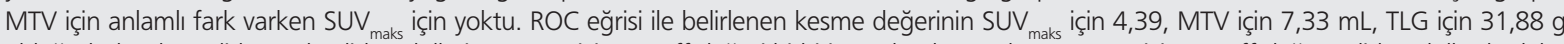
olduğu bulundu. Solid ve subsolid nodüllerin SUV ${ }_{\text {maks }}$ için cut-off değeri birbirine yakındı, ancak MTV, TLG için cut-off değer solid nodüllerde daha yüksekti.

Address for Correspondence: Mehmet Erdoğan MD, Süleyman Demirel University Faculty of Medicine, Department of Nuclear Medicine, Isparta, Turkey Phone: +90 5309257530 E-mail: mdr_erdogan@yahoo.com ORCID ID: orcid.org/0000-0001-7724-778X Received: 17.05.2019 Accepted: 05.08.2019 
Sonuç: SUV maks' $_{1}$ MTV ve TLG çap ve atenüasyondan etkilenmektedir. Solid ve subsolid nodüller için farklı MTV ve TLG cut-off değerlerinin

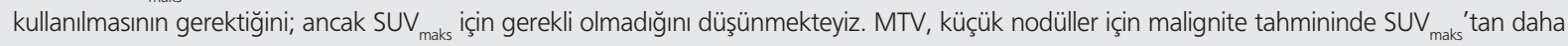
güvenilir bir parametre olabilir.

Anahtar kelimeler: Pozitron emisyon tomografi, soliter pulmoner nodül, metabolik tümör volümü, total lezyon glikolizis

\section{Introduction}

A solitary pulmonary nodule (SPN) is a well-defined, round or oval lesion with a diameter less than $3 \mathrm{~cm}$, surrounded by normal parenchyma, not associated with atelectasis, lymphadenopathy, pneumonia and pleural effusion $(1,2)$. SPNs are detected in $0.9-2 \%$ of chest X-rays and $90 \%$ of them are seen incidentally (3). Multidetector computed tomography (MDCT) allows detection of nodules with smaller sizes, even with diameter of 1-5 mm, which results in increase in detection rates of SPNs ranging between 8-51\% $(4,5)$. SPNs are classified as solid and subsolid nodules. Subsolid nodules can be either pure ground glass opacity (GGO) or semisolid (SS). The etiology of SPNs can be benign or malignant. If MDCT and follow-up imaging findings are indeterminate, ${ }^{18} \mathrm{~F}-\mathrm{FDG}$ positron emission tomography (PET)/ CT or biopsy is needed for precise diagnosis $(6,7)$. ${ }^{18} \mathrm{~F}-\mathrm{FDG}$ $\mathrm{PET} / \mathrm{CT}$ is a non-invasive technique that demonstrates the amount of glucose metabolism used by metabolically active cells, gives morphological information and provides differentiation between malignant and benign lesions (8). A standardized uptake value (SUV) is a semiquantitative method for evaluation of ${ }^{18} \mathrm{~F}$-FDG uptake besides qualitative interpretation with the PET scans. The maximum SUV $\left(\mathrm{SUV}_{\max }\right)>2.5$ is accepted as a threshold value for malignant lesions, although there can be some variations in the literature $(8,9,10,11)$. On the other hand, ${ }^{18} \mathrm{~F}-\mathrm{FDG}$ avidity can also be observed in benign conditions such as inflammation, infection; or malignant diseases can be less avid secondary to volumetric effects such as nodule size $(12,13,14,15,16,17,18,19)$. Kim et al. (20) has mentioned that, SUV ${ }_{\max }$ values of half of the bronchoalveolar carcinoma and carcinoid tumors, which constitute $2 \%$ of all lung cancers, cause false negative PET results.

Metabolic activity of the lesions can be measured with volumetric parameters, metabolic tumor volume (MTV) and total lesion glycolysis (TLG). The MTV is a volumetric measurement of tumor cells measured by semi-automatic delineation tools using a specific threshold of SUV. TLG is defined as the product of the mean SUV and the MTV. SUV $V_{\text {mean }}$ is the mean value of SUV in a chosen region (21).

The aim of this study was to evaluate morphological and metabolic activity parameters for SPNs and the effects of morphological characteristics of the nodule on metabolic activity assessment. To the best of our knowledge, this is the first study to compare the volumetric metabolic activity parameters according to the morphologic parameters of the nodules.

\section{Materials and Methods}

${ }^{18} \mathrm{~F}-\mathrm{FDG}$ PET/CT scans were performed in a LutetiumYttrium Oxyorthosilicate (LYSO) PET/64-slice CT scanner (Philips Gemini TF) for pulmonary nodule assessment between 2011 and 2018. PET/CT images were evaluated retrospectively by a nuclear radiologist with 8 years of experience (M.E.). Approval from the local research ethics committee was granted. One hundred thirteen SPNs with biopsy-proven diagnosis were included in the study. Histopathological findings were accepted as the gold standard method. Patients with multiple nodules, and calcified nodules were excluded.

Non-contrast Thorax CT scans were performed with Siemens Somatom Definition AS, 128 slice CT machine. Imaging parameters were as follows; automatic effective $\mathrm{mA}, 120 \mathrm{kVp}$, gantry rotation speed $0.5 \mathrm{sec}$, slice thickness $1 \mathrm{~mm}$. Images were retrospectively evaluated by a diagnostic radiologist with 15 years of experience (H.A). The radiologist was blinded to the histopathology and PET findings. Nodule size, location, margins, density, vascular sign, and pleural tag were evaluated individually. SPNs were classified as solid, SS, GGO nodules according to their densities. Besides, their densities were calculated by region of interest (ROI) replacement in Hounsfield unit (HU).

${ }^{18}$ F-FDG PET/CT scans were performed after 6-hours fastening. Three point seven $\mathrm{MBq} / \mathrm{kg}(0.1 \mathrm{mCi} / \mathrm{kg}){ }^{18} \mathrm{~F}-\mathrm{FDG}$ was given by intravenous injection. PET and CT images (non-corrected and attenuation-corrected) were obtained using maximum intensity projection and cross-sectional methods. SUV ${ }_{\text {max' }}$ metabolic activity volumetric parameters such as MTV, and TLG were calculated. MTV was calculated by $\mathrm{ROI}$ replacement in metabolically active area in each slice. TLG was calculated as the product of SUV ${ }_{\text {mean }}$ and MTV $\left(S_{\text {max }}\right)>2.5$ was accepted as a threshold value for malignant lesions (Figure 1, 2).

Both of the diagnostic radiologist and the nuclear radiologist made a final assessment for prediction of benignity or malignancy, independently from each other. 


\section{Statistical Analysis}

Statistical analyses of the study were performed by SPSS 20.0 (IBM Inc., Chicago, IL, USA). Descriptive statistics were presented as mean \pm standard deviation for continuous variables and as frequency (percentage) for categorical variables with tables. Normality of continuous variables were checked by the Kolmogorov-Smirnov test. MannWhitney $\mathrm{U}$ for two independent groups and Kruskal-Wallis tests for multiple groups were used to compare continuous numerical data since there was no normal distribution. ROC analysis was performed for SUV ${ }_{\max }$ and MTV values according to malignancy status and cut-off values were determined. Differential diagnosis rates such as specificity, sensitivity, accuracy and Kappa coefficients were calculated by comparing histopathological, radiological and nuclear medical evaluations. Monte Carlo corrected chi-square analysis was performed to determine the relationship between histopathological tumor subtypes and other categorical variables. $\mathrm{P}<0.05$ was considered as statistically significant result by assuming a type 1 error value of $5 \%$ in all analyses.

\section{Results}

The vast majority $(79.6 \%)$ of patients were male and the average age was $67.88 \pm 10.75$ years (median=68). According to the histopathological diagnosis, 16.8\% $(n=19)$ of SPNs were benign, and $83.2 \% \quad(n=94)$ were malignant (Table 1). Malignancy subtypes were adenocarcinoma (37.2\%), squamous cell carcinoma (SCC) $(25.7 \%)$, small cell carcinoma (15.9\%), carcinoid tumor $(2.7 \%)$ and bronchoalveolar carcinoma. Metastasis was detected in one patient. The distribution of SPNs according to attenuation was; solid (77.9\%), SS (15.9\%) and GGO $(6.2 \%)$, respectively.

Spiculated margin, vascular sign, and pleural tag presence were predominantly observed in the malignant group (Table 1). The attenuation distribution of nodules was; solid, SS, and GGO, respectively (Table 1). SPN diameter, SUV max' $, M T V, T L G$, and density values were significantly different between the malignant and benign SPNs according to the histopathologic results. Those parameters were significantly higher in the malignant group (Table 1, 2). However, no significant difference was found amongst the malignant subtypes.

SUV max $_{\text {m }}$ MTV, and TLG increased in direct proportion to the SPN diameter ( $R$ values were $0.53,0.70$ and 0.75 respectively, $p<0.001)$. When we separated SPNs in two groups according to diameter, such as $<2 \mathrm{~cm}$ and $\geq 2 \mathrm{~cm}$, there was a significant difference between groups in terms of MTV $(p<0.001)$, while there was no difference in terms of SUV ${ }_{\text {max }}(p=0.096)$ (Table 3). According to margin classification, most of the well-defined ones were SCC, lobulated ones were adenocarcinoma, and spiculated ones were small cell carcinoma and SCC $(p=0.036)$.

According to threshold value of 2.5; the sensitivity, specificity, accuracy, positive predictive value (PPV), and negative predictive value (NPV) of SUV ${ }_{\text {max }}$ were found as 98.9\%, 52.6\%, 91.1\%, 91.1\%, and 90.9\%, respectively (Kappa=0.620). On the other hand, sensitivity, specificity, accuracy, PPV, and NPV of final diagnosis of CT evaluation were calculated as $90.4 \%, 63.1 \%, 85.8 \%, 92.3 \%$, and $57.1 \%$, respectively (Kappa $=0.514$ ).

The cut-off value calculated by the ROC curve analysis for SUV max , based on the likelihood of malignancy, was found to be 4.39 (sensitivity $93.6 \%$, specificity $89.5 \%$ and accuracy 92.9\%), (AUC $=0.950 \pm 0.027 ; p<0.001$ ) (Figure 3). Similarly,
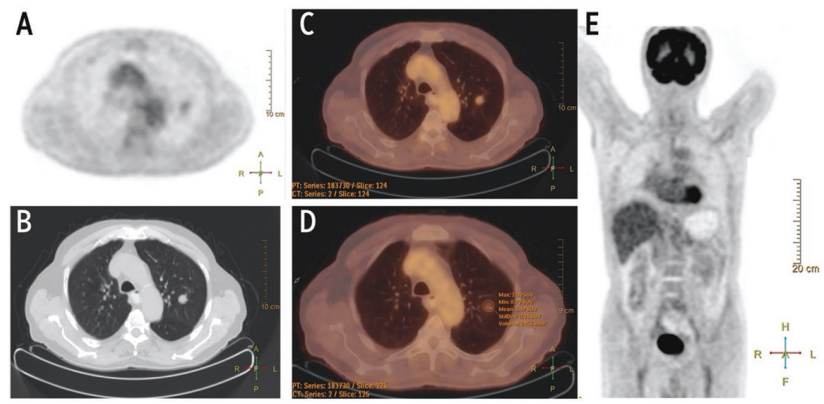

Figure 1. A well-defined and solid solitary pulmonary nodules was detected in left upper lobe in positron emission tomography (PET) image. (A) Axial non-contrast Thorax computed tomography (CT) at parenchyma window (B), and PET/CT image (C). Measurement of activity parameters were consistent with benign lesions on PET/ CT image (D). MIP image of total body PET showed no significant activity (E)
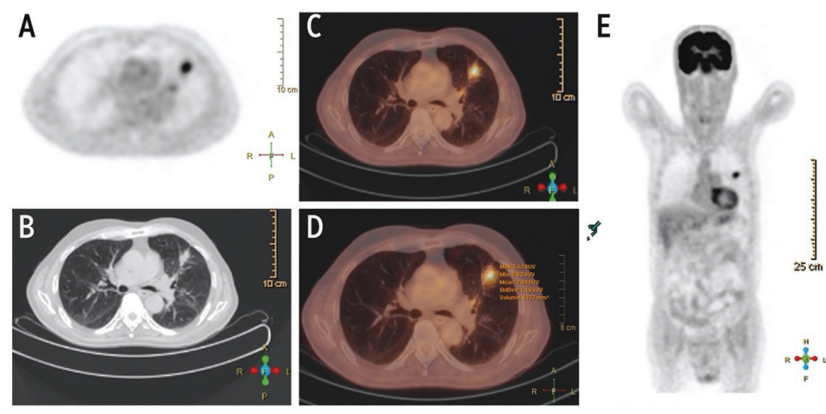

Figure 2. A spiculated and solid solitary pulmonary nodules was detected in left upper lobe in positron emission tomography (PET) image. (A) Axial non-contrast Thorax computed tomography (CT) at parenchyma window (B), and PET/CT image (C). Measurement of activity parameters were consistent with malignancy on PET/CT image (D). MIP image of total body PET showed significant activity in left upper lobe (E) 
ROC analysis for MTV measurements calculated the cutoff value as 7.33 (AUC $=0.774 \pm 0.066 ; p<0.001$ ) (sensitivity $79.8 \%$, specificity $68.4 \%$, accuracy $77.9 \%$ ) (Figure 3 ). The cut-off value calculated for TLG measurements was $31.88 \mathrm{~g}(\mathrm{AUC}=0.891 \pm 0.039 ; \mathrm{p}<0.001)$ (sensitivity $76.6 \%$, specificity $89.5 \%$, accuracy $78.8 \%$ ) (Figure 3 ). The cut-off value calculated for the density was $2.5 \mathrm{HU}$, while the ROC curve was found to be significant ( $A \cup C=0.694 \pm 0.080$; $\mathrm{p}=0.008$ ) (Figure 3).

In both benign and malignant groups, there was no significant difference between SUV $_{\max }$ values amongst GGO, SS and solid nodules. In benign group MTV and TLG values increased in parallel with the density of the nodules, but no significant difference was found. On the other hand, in malignant group, both MTV and TLG values increased in direct proportion to the density of the nodules, significantly (Table 4). Cut-off values of SUV $\max ^{\prime}, M T V, T L G$ for subsolid SPNs were 4.41, 5.22 and 14.06, respectively.

\begin{tabular}{|c|c|c|c|c|}
\hline & & $\begin{array}{l}\text { Benign } \\
(n=19)\end{array}$ & $\begin{array}{l}\text { Malignant } \\
(n=94)\end{array}$ & $\mathbf{p}$ \\
\hline & & \multicolumn{2}{|l|}{ Mean \pm SD } & \\
\hline \multicolumn{2}{|l|}{ Age } & $66.00 \pm 14.95$ & $68.39 \pm 9.74$ & 0.605 \\
\hline \multirow[t]{2}{*}{ Gender } & Male & $13(68.4)$ & 77 (81.9) & 0.185 \\
\hline & Female & $6(31.6)$ & $17(18.1)$ & \\
\hline $\begin{array}{l}\text { SPN } \\
\text { diameter }\end{array}$ & $\mathrm{mm}$ & $18.73 \pm 8.10$ & $27.02 \pm 6.47$ & 0.002 \\
\hline \multirow[t]{2}{*}{$\begin{array}{l}\text { Density } \\
\text { (HU) }\end{array}$} & & $4.78 \pm 42.37$ & $20.38 \pm 32.75$ & 0.008 \\
\hline & & n (\%) & n (\%) & \\
\hline \multirow[t]{3}{*}{ Attenuation } & GGO & $3(15.8)$ & $4(4.3)$ & \multirow[t]{3}{*}{0.001} \\
\hline & PS & $7(36.8)^{a}$ & $11(11.7)^{b}$ & \\
\hline & Solid & $9(47.4)^{a}$ & $79(84.0)^{b}$ & \\
\hline \multirow[t]{3}{*}{ Margins } & Well-defined & $10(52.6)^{a}$ & $7(7.4)^{b}$ & \multirow[t]{3}{*}{$<0.001$} \\
\hline & Lobulated & $5(26.3)$ & $30(31.9)$ & \\
\hline & Spiculated & $4(21.1)^{a}$ & $57(60.6)^{b}$ & \\
\hline \multirow{2}{*}{$\begin{array}{l}\text { Vascular } \\
\text { sign }\end{array}$} & $(-)$ & $13(68.4)$ & $38(40.4)$ & \multirow[t]{2}{*}{0.026} \\
\hline & $(+)$ & $6(31.6)$ & $56(59.6)$ & \\
\hline \multirow[t]{2}{*}{ Pleural tag } & $(-)$ & $13(68.4)$ & $38(40.4)$ & \multirow[t]{2}{*}{0.026} \\
\hline & $(+)$ & $6(31.6)$ & $56(59.6)$ & \\
\hline \multirow[t]{2}{*}{ Localization } & Central & $3(14.8)^{a}$ & $42(44.7)^{b}$ & \multirow[t]{2}{*}{0.048} \\
\hline & Peripheral & $16(84.2)^{a}$ & $52(55.3)^{b}$ & \\
\hline \multicolumn{5}{|c|}{$\begin{array}{l}\text { Mann-Whitney U test and chi-square test. } \\
\text { a,b: Significantly different categories. } \\
\text { GGO: Ground glass opacity, PS: Partially solid, SD: Standard deviation, HU: } \\
\text { Hounsfield unit, SPN: Solitary pulmonary nodule }\end{array}$} \\
\hline
\end{tabular}

Cut-off values of SUV max' MTV, and TLG for solid SPNs were $4.39,17.53$ and 73.38 , respectively (Table 5 ).

\section{Discussion}

We investigated the morphological and metabolic activity parameters for SPNs and the effect of morphological characteristics of the nodule on metabolic activity assessment (SUV ${ }_{\max }$ and volumetric parameters such as MTV and TLG). In this study, we compared the ${ }^{18} \mathrm{~F}-\mathrm{FDG}$ PET and CT findings of SPNs with histopathological diagnosis of 113 patients. Ninety four of them (83.2\%) were malignant and 19 of them (16.8\%) were benign.

We accepted SUV max $_{\text {ax }}>2.5$ as a threshold value for malignant nodules and $\leq 2.5$ for benign nodules in ${ }^{18}$ F-FDG PET evaluation, similarly with most of the studies in literature $(8,9,10,11)$. However, ${ }^{18} \mathrm{~F}$-FDG avidity can also be observed in benign conditions such as inflammation, infection;
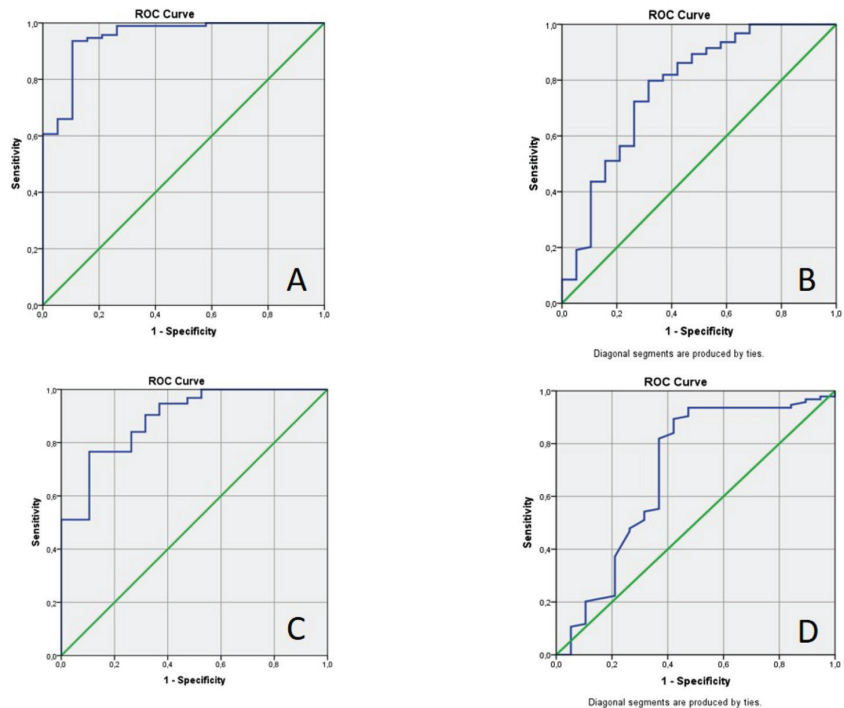

Figure 3. ROC analysis of SUV ${ }_{\max }(\mathrm{A})$, metabolic tumor volume (B), total lesion glycolysis (C), and density (D) for malignancy

Table 2. Positron emission tomography/computed tomography findings of benign and malignant solitary pulmonary nodules

\begin{tabular}{|c|c|c|c|}
\hline & Benign $(n=19)$ & Malignant ( $n=94)$ & $\mathbf{p}$ \\
\hline & Mean \pm SD & & \\
\hline SUV $_{\max }$ & $2.98 \pm 2.11$ & $11.94 \pm 19.17$ & $<0.001$ \\
\hline MTV (mL) & $8.88 \pm 10.91$ & $19.17 \pm 14.34$ & $<0.001$ \\
\hline TLG (g) & $17.79 \pm 20.57$ & $103.11 \pm 90.68$ & $<0.001$ \\
\hline $\begin{array}{l}\text { Mann-Whitne } \\
\text { a, b: Significant } \\
\text { SD: Standard }\end{array}$ & $\begin{array}{l}\text { t \& chi-square test. } \\
\text { rent categories. } \\
\text { on, MTV: Metabolic }\end{array}$ & nor volume, TLG: Total le & n glycolysis \\
\hline
\end{tabular}


or malignant diseases can be less avid secondary to volumetric effects such as nodule size, ROI placement, etc. $(12,13,14,15,16,17,18,19)$. SUV ${ }_{\max }$ values of half of the bronchoalveolar carcinoma and carcinoid tumors which constitute $2 \%$ of all lung cancers, may cause false negative PET results (20).

\begin{tabular}{|c|c|c|c|c|}
\hline Diameter & & SUV $_{\text {max }}$ & MTV & TLG \\
\hline \multirow[t]{2}{*}{$(n=113)$} & $\mathbf{R}$ & 0.526 & 0.695 & 0.752 \\
\hline & $\mathbf{p}$ & $<0.001$ * & $<0.001$ * & $<0.001^{*}$ \\
\hline \multicolumn{5}{|l|}{ Benign } \\
\hline \multirow[t]{2}{*}{$(n=19)$} & $\mathbf{R}$ & 0.306 & 0.822 & 0.794 \\
\hline & $p$ & 0.203 & $<0.001^{*}$ & $<0.001$ \\
\hline \multicolumn{5}{|l|}{ Malignant } \\
\hline \multirow[t]{2}{*}{$(n=94)$} & $\mathbf{R}$ & 0.389 & 0.554 & 0.604 \\
\hline & $\mathbf{p}$ & $<0.001^{*}$ & $<0.001^{*}$ & $<0.001$ \\
\hline \multicolumn{5}{|l|}{$<20 \mathrm{~mm}$} \\
\hline \multirow[t]{2}{*}{$(n=31)$} & $\mathbf{R}$ & 0.304 & 0.582 & 0.352 \\
\hline & $p$ & 0.096 & $0.001^{*}$ & 0.052 \\
\hline \multicolumn{5}{|l|}{$\geq 20 \mathrm{~mm}$} \\
\hline \multirow[t]{2}{*}{$(n=82)$} & $\mathbf{R}$ & 0.195 & 0.463 & 0.482 \\
\hline & $p$ & 0.078 & $<0.001^{*}$ & $<0.001$ \\
\hline
\end{tabular}

Table 4. ${ }^{18} \mathrm{~F}-\mathrm{FDG}$ positron emission tomography/computed

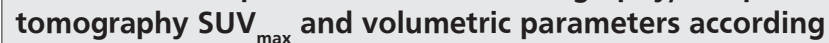
to attenuation classification

\begin{tabular}{|c|c|c|c|c|}
\hline \multirow{2}{*}{ Benign } & GGO $(n=3)$ & PS $(n=7)$ & Solid $(n=9)$ & \multirow[b]{2}{*}{$r$} \\
\hline & \multicolumn{3}{|c|}{ Mean \pm SD } & \\
\hline$S U V_{\max }$ & $1.86 \pm 1.01$ & $3.14 \pm 2.31$ & $3.22 \pm 2.28$ & 0.653 \\
\hline $\operatorname{MTV}(\mathrm{mL})$ & $1.27 \pm 1.29$ & $5.33 \pm 2.34$ & $14.18 \pm 14.11$ & 0.060 \\
\hline TLG (g) & $2.26 \pm 2.99$ & $10.86 \pm 9.92$ & $28.35 \pm 24.86$ & 0.071 \\
\hline Dansite & $-56.67 \pm 45.09^{a}$ & $-0.28 \pm 13.03$ & $29.22 \pm 35.97^{b}$ & 0.011 \\
\hline Malign & $(n=4)$ & $(n=11)$ & $(n=79)$ & \\
\hline$S U V_{\max }$ & $7.60 \pm 4.23$ & $9.38 \pm 6.62$ & $12.52 \pm 20.72$ & 0.191 \\
\hline $\operatorname{MTV}(\mathrm{mL})$ & $13.05 \pm 10.04$ & $8.59 \pm 7.09^{a}$ & $20.95 \pm 14.62^{b}$ & 0.002 \\
\hline TLG (g) & $62.94 \pm 63.91$ & $41.78 \pm 53.11^{a}$ & $113.69 \pm 92.52^{b}$ & 0.002 \\
\hline $\begin{array}{l}\text { Density } \\
(\mathrm{HU})\end{array}$ & $-60.0 \pm 64.42^{a}$ & $-12.81 \pm 46.82^{c}$ & $29.08 \pm 16.57^{b, d}$ & $<0.001$ \\
\hline \multicolumn{5}{|c|}{$\begin{array}{l}\text { Kruskal-Wallis test. } \\
\text { a,b and c,d: Significantly different categories. } \\
\text { GGO: Ground glass opacity, PS: Partially solid, MTV: Metabolic tumor volume, TLG: } \\
\text { Total lesion glycolysis, HU: Hounsfield unit }\end{array}$} \\
\hline
\end{tabular}

In our study, sensitivity, specificity, accuracy, PPV and NPV were $98.9 \%, 52.6 \%, 91.1 \%, 91.1 \%$, and $90.9 \%$, respectively (Kappa $=0,620)$ in comparison with histopathological findings. In a study by Orlacchio et al. (22), the sensitivity, specificity and accuracy were calculated as 76.9\%, 100\%, and $89.2 \%$ according to SUV max $_{\text {max }}$ threshold of 2.5 in benign (46.4\%) and malign (53.6\%) SPNs. Opoka et al. (23) calculated $95 \%$ sensitivity, $88 \%$ specificity, $91.5 \%$ accuracy in their study using SUV max $_{\text {max }}$ threshold value of 2.5 in 40 malignant and 42 benign SPNs. Although we found higher sensitivity, the specificity was lower, and the accuracy was similar in comparison with Orlacchio et al's. (22) study. We think that, this may result from small patient population in benign group in our study. In addition, 9 of the 19 benign SPNs had infectious etiology in our study. SPNs with infectious, inflammatory, granulomatous etiology can cause higher ${ }^{18}$ F-FDG avidity (11). Deppen et al. (24) found similar sensitivity (92\%) and specificity (40\%) in their study performed in a region of endemic granulomatous diseases.

Grgic et al. (10) evaluated malignancy ratios of 140 patients with using different SUV ${ }_{\text {max }}$ threshold value and found that more than $90 \%$ of nodules with SUV ${ }_{\max }<2$ were benign. Sensitivity, specificity and NPV were 96\%, 55\%, and 92\%, respectively. The highest diagnostic accuracy was found with SUV max $_{\text {max }}$ threshold of 4 (sensitivity, specificity and accuracy of $85 \%$ ). ROC analysis in a study with 88 SPNs by Hou et al. (25) showed SUV max $>3.635$ as the best threshold value for SPNs (sensitivity $83.3 \%$, sensitivity $62.5 \%$, accuracy $79.2 \%$ ). In our study, ROC analysis demonstrated

Table 5. Cut-off values of SUV , metabolic tumor volume, total lesion glycolysis for subsolid and solid solitary pulmonary nodules

\begin{tabular}{|c|c|c|c|c|}
\hline & & SUV $_{\text {max }}$ & MTV & TLG \\
\hline Subsolid & $n=25$ & $6.44 \pm 5.64$ & $7.52 \pm 6.85$ & $31.77 \pm 46.42$ \\
\hline \multirow[t]{2}{*}{ Solid } & $n=88$ & $9.63 \pm 4.96$ & $20.26 \pm 14.64$ & $104.96 \pm 91.69$ \\
\hline & $p$ & 0.001 & $<0.001^{\star}$ & $<0.001^{*}$ \\
\hline \multirow[t]{3}{*}{ Subsolid } & AUC & 0.900 & 0.760 & 0.913 \\
\hline & Cut-off & 4.41 & 5.215 & 14.065 \\
\hline & & $\begin{array}{l}\text { Sens }=93.6 \% \\
\text { Spec }=89.4 \% \\
\text { Accu }=92.9 \%\end{array}$ & $\begin{array}{l}73.33 \% \\
70.0 \% \\
72.0 \%\end{array}$ & $\begin{array}{l}86.67 \% \\
90.0 \% \\
880 \%\end{array}$ \\
\hline \multirow[t]{3}{*}{ Solid } & AUC & 0.954 & $0.652 * *$ & 0.850 \\
\hline & Cut-off & 4.39 & 17.53 & 73.38 \\
\hline & & $\begin{array}{l}\text { Sens }=93.6 \% \\
\text { Spec }=89.4 \% \\
\text { Accu }=92.9 \%\end{array}$ & & $\begin{array}{l}96.2 \% \\
22.2 \% \\
88.6 \%\end{array}$ \\
\hline
\end{tabular}

* Statistically significant at $p<0.05$ level.

** Not significant.

MTV: Metabolic tumor volume, TLG: Total lesion glycolysis 
(AUC $=0.950 \pm 0.027 ; p<0.001)_{\text {) SUV }}$ max $_{\text {mat }}$ cutf value as 4.39 for malignant nodules, similar with the study by Grgic et al. (10) and higher than the study by Hou et al. (25) (sensitivity 93.6\%, specificity $89.5 \%$ and accuracy $92.9 \%$ ). Sensitivity, specificity and accuracy values for threshold value of 4.39 were also higher than both two studies.

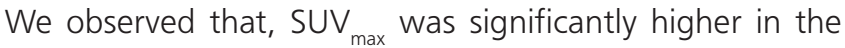
malignant group. However, no significant difference was found amongst the malignant histopathologic subtypes. Also, Divisi et al. (12) found no significant correlation between histopathological findings and $\operatorname{SUV}_{\max }(p=0.586)$. Davidson et al. (26) showed that SCC was more ${ }^{18} \mathrm{~F}-\mathrm{FDG}$ avid than adenocarcinoma.

Volumetric parameters developed for measuring metabolic activity are MTV, and TLG in PET scans. In our study, there was a significant difference between malignant and benign nodules in terms of MTV and TLG values. All of the measurements were significantly higher in malignant group. However, there was no significant difference amongst the malignant histopathologic subtypes. ROC analysis showed cut-off value of $7.33 \mathrm{~mL}$ for MTV (AUC $=0.774 \pm 0.066$; $p<0.001$ ) (sensitivity $79.8 \%$, specificity $68.4 \%$, accuracy $77.9 \%)$ and $31.88 \mathrm{~g}$ for TLG (AUC $=0.891 \pm 0.039 ; \mathrm{p}<0.001)$ (sensitivity $76.6 \%$, specificity $89.5 \%$, accuracy $78.8 \%$ ). There has been a few studies in literature researching the relationship between volumetric parameters and prognosis in small cell lung cancer, mesothelioma, non-small cell lung cancers $(27,28,29)$. However, according to our literature search, this is the first study to evaluate the volumetric parameters in SPNs.

Winer-Muram (30) has declared that the probability of malignancy increases with the size. Kim et al. (31) observed

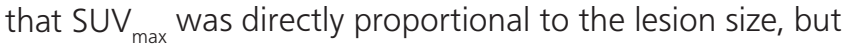
inversely proportional to the GGO percentage. Divisi et al. (12) and Khalaf et al. (32) found consistent results with the study by Kim et al. (31) in terms of relation between nodule size and SUV $\mathrm{max}_{\text {. }}$

We also observed that SPN diameter was significantly larger in the malignant group. In addition, SUV max' MTV, TLG increased in direct proportion to the SPN diameter ( $R$ values were $0.53,0.70$ and 0.75 , respectively, $p<0.001$ ). When we separated SPNs according to diameter into two groups, such as $<2 \mathrm{~cm}$ and $\geq 2 \mathrm{~cm}$, there was a significant difference between groups in terms of MTV $(p<0.001)$, while there was no difference between groups in terms of $\mathrm{SUV}_{\max }(p=0.096)$. Therefore, MTV can be a more reliable parameter than SUV max $_{\text {max }}$ in prediction of malignancy in smaller nodules $(p<0.001)$.

Zhou et al. (33) and Nakamura et al. (34) mentioned that solid component predominancy increases by the invasiveness of adenomatous lung lesions in SS nodules.
Our study showed that malignancy rates were directly proportional to the density. On the contrary, there was no significant difference in density measurements of subsolid nodules between benign and malignant group $(p=0.70)$.

Chun et al. (35) revealed that SUV max $_{\text {max }}$ of SS nodules was higher in benign inflammatory group than in malignant group, but there was no significant difference between groups in terms of GGO nodules. They concluded that follow-up was recommended instead of immediate biopsy for such cases. Nomori et al. (17) evaluated 15 GGO and 101 solid nodules in their study and concluded that ${ }^{18} \mathrm{~F}-\mathrm{FDG}$ PET was not a feasible method for GGO nodules because of having lower sensitivity (10\%) and specificity (20\%), unlike it was a feasible method for solid nodules because of having higher sensitivity (90\%) and specificity (71\%). We observed no significant difference amongst GGO, SS and solid nodules neither in benign nor malignant group in terms of SUV $V_{\text {max }}$ values. In both benign and malignant groups, MTV and TLG values increased in parallel with the density of the nodules, but significant difference was only found in malignant group. SUV ${ }_{\max }$ cut-off value of solid and subsolid nodules were considerably close to each other, but MTV and TLG were higher in solid nodules than the other groups. Thus, we think that there is a need for using different cut-off levels of MTV and TLG for solid and subsolid nodules, but there is no need for using different cut-off level of SUV ${ }_{\text {max }}$.

\section{Study Limitations}

The limitations of our study can be listed as follows; (1) the histopathological findings were results of tru-cut biopsy, not lobectomy, (2) biopsies were performed for only malignancy suspected nodules, others were followed-up radiologically. That was the reason why we had a smaller patient group in the benign group.

\section{Conclusion}

MDCT or ${ }^{18} \mathrm{~F}-\mathrm{FDG}$ PET findings can be indeterminate for malignancy prediction of SPNs on their own, and should be interpreted together. Metabolic activity assessment can be done by measurements of SUV $\mathrm{max}_{\text {max }}$ and volumetric parameters such as MTV and TLG on PET scans. They are all expected to be found higher in malignancy. However, these parameters are affected by morphological characteristics, such as diameter and attenuation of the nodule. According to these differences, it is controversial which parameter is more reliable. We think that, there is a need for using different cut-off levels of MTV and TLG for solid and subsolid nodules, but there is no need for using different cut-off level of SUV ${ }_{\max }$. MTV can be a more 
reliable parameter than $S U V_{\text {max }}$ in prediction of malignancy in smaller nodules $(<2 \mathrm{~cm})$. We suggest that, further studies are needed for evaluation of volumetric parameters in SPNs.

\section{Ethics}

Ethics Committee Approval: Approval from the Süleyman Demirel University Local Research Ethics Committee was granted (desicion no: 138, 04.07.2018).

Informed Consent: Retrospective study.

Peer-review: Externally peer-reviewed.

\section{Authorship Contributions}

Surgical and Medical Practices: M.E., S.S.Ş., Concept: M.E., Design: S..E., Data Collection or Processing: H.A., Analysis or Interpretation: A.K., Literature Search: M.E., Ş.E., Writing: M.E., Ş.E..

Conflict of Interest: No conflict of interest was declared by the authors.

Financial Disclosure: The authors declared that this study received no financial support.

\section{References}

1. Tuddenham WJ. Glossary of terms for thoracic radiology: recommendations of the Nomenclature Committee of the Fleischner Society. AJR Am J Roentgenol 1984;143:509-517.

2. Ost $D$, Fein $A M$, Feinsilver $\mathrm{SH}$. Clinical practice. The solitary pulmonary nodule. N Engl J Med 2003;348:2535-2542.

3. Midthun DE, Swensen SJj, Jett JR, editors. Approach to the solitary pulmonary nodule. Mayo Clin Proc 1993;68:378-385.

4. Gohagan J, Marcus P, Fagerstrom R, Pinsky P, Kramer B, Prorok P; Writing Committee, Lung Screening Study Research Group. Baseline findings of a randomized feasibility trial of lung cancer screening with spiral CT scan vs chest radiograph: the Lung Screening Study of the National Cancer Institute. Chest 2004;126:114-121.

5. Swensen SJ, Jett JR, Hartman TE, Midthun DE, Sloan JA, Sykes AM, Aughenbaugh GL, Clemens MA. Lung cancer screening with CT: Mayo Clinic experience. Radiology 2003;226:756-761.

6. Lee HY, Lee KS. Ground-glass opacity nodules: histopathology, imaging evaluation, and clinical implications. J Thorac Imaging 2011;26:106-118.

7. Naidich DP, Bankier AA, MacMahon H, Schaefer-Prokop CM, Pistolesi M, Goo JM, Macchiarini P, Crapo JD, Herold CJ, Austin JH, Travis WD. Recommendations for the management of subsolid pulmonary nodules detected at CT: a statement from the Fleischner Society. Radiology 2013;266:304-317.

8. Sim YT, Poon FW. Imaging of solitary pulmonary nodule-a clinical review. Quant Imaging Med Surg 2013;3:316-326.

9. Herder GJ, van Tinteren H, Golding RP, Kostense PJ, Comans EF, Smit EF, Hoekstra OS. Clinical prediction model to characterize pulmonary nodules: validation and added value of $18 \mathrm{~F}$-fluorodeoxyglucose positron emission tomography. Chest 2005;128:2490-2496.

10. Grgic A, Yüksel Y, Gröschel A, Schäfers H-J, Sybrecht GW, Kirsch CM, Hellwig D. Risk stratification of solitary pulmonary nodules by means of PET using 18 F-fluorodeoxyglucose and SUV quantification. Eur J Nucl Med Mol Imaging 2010;37:1087-1094.
11. Gould MK, Fletcher J, lannettoni MD, Lynch WR, Midthun DE, Naidich DP, Ost DE; American College of Chest Physicians. Evaluation of patients with pulmonary nodules: when is it lung cancer?: ACCP evidence-based clinical practice guidelines. Chest 2007;132:108-130.

12. Divisi D, Barone M, Bertolaccini L, Rocco G, Solli P, Crisci R; Italian VATS Groupl. Standardized uptake value and radiological density attenuation as predictive and prognostic factors in patients with solitary pulmonary nodules: our experience on 1,592 patients. J Thorac Dis 2017;9:25512559.

13. Chen CJ, Lee BF, Yao WJ, Cheng L, Wu PS, Chu CL, Chiu NT. Dualphase 18F-FDG PET in the diagnosis of pulmonary nodules with an initial standard uptake value less than 2.5. AJR Am J Roentgenol 2008;191:475-479.

14. Erasmus JJ, McAdams HP, Patz EF Jr, Coleman RE, Ahuja V, Goodman PC. Evaluation of primary pulmonary carcinoid tumors using FDG PET. AJR Am J Roentgenol 1998;170:1369-1373.

15. Heyneman LE, Patz EF. PET imaging in patients with bronchioloalveolar cell carcinoma. Lung Cancer 2002;38:261-266.

16. Kapucu LO, Meltzer CC, Townsend DW, Keenan RJ, Luketich JD. Fluorine18-fluorodeoxyglucose uptake in pneumonia. J Nucl Med 1998;39:12671269.

17. Nomori $H$, Watanabe $K$, Ohtsuka $T$, Naruke $T$, Suemasu $K$, Uno $K$. Evaluation of F-18 fluorodeoxyglucose (FDG) PET scanning for pulmonary nodules less than $3 \mathrm{~cm}$ in diameter, with special reference to the CT images. Lung Cancer 2004;45:19-27.

18. Ollenberger GP, Knight $\mathrm{S}$, Tauro AJ. False-positive FDG positron emission tomography in pulmonary amyloidosis. Clin Nucl Med 2004;29:657-658.

19. Thie JA. Understanding the standardized uptake value, its methods, and implications for usage. J Nucl Med 2004;45:1431-1434.

20. Kim B, Kim Y, Lee K, Yoon S, Cheon E, Kwon O, Rhee CH, Han J, Shin MH. Localized form of bronchioloalveolar carcinoma: FDG PET findings. AJR Am J Roentgenol 1998;170:935-939.

21. Moon SH, Hyun SH, Choi JY. Prognostic significance of volume-based PET parameters in cancer patients. Korean J Radiol 2013;14:1-12.

22. Orlacchio A, Schillaci O, Antonelli L, D'Urso S, Sergiacomi G, Nicoli P, Simonetti G. Solitary pulmonary nodules: morphological and metabolic characterisation by FDG-PET-MDCT. Radiol Med 2007;112:157-173.

23. Opoka L, Kunikowska J, Podgajny Z, Szołkowska M, Błasińska-Przerwa K, Burakowska B, Oniszh K, Rudziński P, Bestry I, Roszkowski-Śliż K. Accuracy of FDG PET/CT in the evaluation of solitary pulmonary lesions - own experience. Pneumonol Alergol Pol 2014;82:198-205.

24. Deppen S, Putnam JB Jr, Andrade G, Speroff T, Nesbitt JC, Lambright ES, Massion PP, Walker R, Grogan EL. Accuracy of FDG-PET to diagnose lung cancer in a region of endemic granulomatous disease. Ann Thorac Surg 2011:92:428-433.

25. Hou S, Lin X, Wang S, Shen Y, Meng Z, Jia Q, Tan J. Combination of positron emission tomography/computed tomography and chest thinlayer high-resolution computed tomography for evaluation of pulmonary nodules: Correlation with imaging features, maximum standardized uptake value, and pathology. Medicine (Baltimore) 2018;97:e11640.

26. Davidson J, Wong V, Fraser R, Hirsh V. Comparison of primary tumor maximal standardized uptake value (SUVmax) on preoperative (18F) fluorodeoxyglucose positron emission tomography/computed tomography (PET/CT) and histological subtype in patients with non-small cell lung cancer (NSCLC). Journal of Clinical Oncology. 2009;27:7571.

27. Chen HH, Chiu NT, Su WC, Guo HR, Lee BF. Prognostic value of wholebody total lesion glycolysis at pretreatment FDG PET/CT in non-small cell lung cancer. Radiology 2012;264:559-566.

28. Klabatsa A, Chicklore S, Barrington SF, Goh V, Lang-Lazdunski L, Cook GJ. The association of $18 \mathrm{~F}-\mathrm{FDG}$ PET/CT parameters with survival in malignant pleural mesothelioma. Eur J Nucl Med Mol Imaging 2014;41:276-282. 
29. Zhu D, Ma T, Niu Z, Zheng J, Han A, Zhao S, Yu J. Prognostic significance of metabolic parameters measured by 18F-fluorodeoxyglucose positron emission tomography/computed tomography in patients with small cell lung cancer. Lung cancer 2011;73:332-337.

30. Winer-Muram HT. The solitary pulmonary nodule. Radiology 2006;239:3449.

31. Kim TJ, Park CM, Goo JM, Lee KW. Is there a role for FDG PET in the management of lung cancer manifesting predominantly as ground-glass opacity? AJR Am J Roentgenol 2012;198:83-88.

32. Khalaf M, Abdel-Nabi H, Baker J, Shao Y, Lamonica D, Gona J. Relation between nodule size and 18 F-FDG-PET SUV for malignant and benign pulmonary nodules. J Hematol Oncol 2008;1:13.
33. Zhou J, Li Y, Zhang Y, Liu G, Tan H, Hu Y, Xiao J, Shi H. Solitary ground-glass opacity nodules of stage IA pulmonary adenocarcinoma: combination of 18F-FDG PET/CT and high-resolution computed tomography features to predict invasive adenocarcinoma. Oncotarget 2017;8:23312-23321.

34. Nakamura H, Saji H, Shinmyo T, Tagaya R, Kurimoto N, Koizumi H, Tagagi M. Close association of IASLC/ATS/ERS lung adenocarcinoma subtypes with glucose-uptake in positron emission tomography. Lung Cancer 2015;87:28-33.

35. Chun EJ, Lee HJ, Kang WJ, Kim KG, Goo JM, Park CM, Lee $\mathrm{CH}$. Differentiation between malignancy and inflammation in pulmonary ground-glass nodules: the feasibility of integrated 18F-FDG PET/CT. Lung Cancer 2009;65:180-186. 